\section{Ten-year trends in hospitalizations due to Alzheimer's disease in Brazil: a national-based study}

\author{
Tendência durante dez anos nas internações \\ hospitalares por doença de Alzheimer no Brasil: \\ um estudo de base nacional
}

\section{Tendencias durante diez años en hospitalizaciones provocadas por Alzheimer en Brasil: un estudio de base nacional}

Natan Feter 1,2

Jayne Santos Leite 1

Samuel Carvalho Dumith 3

Airton José Rombaldi 1

\begin{abstract}
Brazil has the second highest age-standardized prevalence of Alzheimer's disease worldwide. However, information about Alzheimer's disease-related hospitalizations in Brazil is scarce despite its economic and social impact. We described temporal trends in hospitalizations related to Alzheimer's disease in Brazil from 2010 to 2019. We conducted a time-series, retrospective, descriptive, national-based study using data from the DATASUS database of the Brazilian Ministry of Health. Hospitalizations, mean days hospitalized, and economic costs from those hospitalizations were extracted from 2010 to 2019. Hospitalizations by Alzheimer's disease increased $87.7 \%$ from 2010 to 2019, with greater increase among men (97.4\%), mixed ethnicity (224\%), 80 years or older (115.1\%), and in the Northeast (172.1\%) and Central West (144.2\%) regions. Although mean days hospitalized decreased in all subgroups, an increasing time trend in hospital admission was observed in the Central West Region. Costs per hospitalization increased for patients aged 50 years or younger and in admissions related to emergency services. Compared with other non-communicable chronic diseases, Alzheimer's disease had the highest increase in absolute number and rate of hospitalizations in Brazil from 2010 to 2019. AD is a public health problem in Brazil. Strategies to reduce its burden are necessary but only if accompanied by greater equality and awareness of this disease.
\end{abstract}

Alzheimer Disease; Hospitalization; Time Series Studies

\author{
Correspondence \\ N. Feter \\ Rua Luís de Camões 625, Pelotas, RS 96055-630, Brasil. \\ natanfeter@hotmail.com \\ 1 Universidade Federal de Pelotas, Pelotas, Brasil. \\ ${ }^{2}$ The University of Queensland, St. Lucia, Australia \\ 3 Universidade Federal do Rio Grande, Rio Grande, Brasil.
}




\section{Introduction}

In 2016, Brazil had the second highest age-standardized prevalence of dementia in the world, affecting about 1.7 million people 1. Alzheimer's disease, which accounts for up to $80 \%$ of all cases of dementia, is a neurodegenerative disease characterized by deterioration of cognitive function, such as memory and physical capacity 2. While in Argentina, Chile, and Uruguay the number of deaths attributable to dementia has decreased by up to $5.3 \% 1$, the mortality rate in Brazil increased annually by $12.5 \%$ from 2000 to 2008 3 . Likewise, the annual total cost per individual living with dementia in Brazil is greater than the global average regardless of disease stage 4.

According to the Scientific Department for Cognitive Neurology and Aging of the Brazilian Academy of Neurology 5, the diagnosis of Alzheimer's disease occurs when cognitive or behavioral symptoms affects at least two of the following domains: memory, executive functions, visual and spatial skills, language, and personality or behavior. Usually together with loss of functional capacity, these problems increased the frequency of hospitalizations in Alzheimer's disease patients 6,7,8. This is particularly concerning since these patients may have an irreversible cognitive and functional decline during hospitalization 9.

About $40 \%$ of all annual hospitalizations from 2000 to 2008 in the United States were people 85 years or older living with dementia 8 . Feng et al. 6 showed that patients with Alzheimer's disease living in community residences are more likely to have any avoidable hospitalization and emergency visit than non-demented older people. Data from the United States 7 revealed that sensitive conditions of ambulatory care, which are related to problems in continuity of care, inefficient resource use, and poor patient outcomes, costed USD 4.7 billion in 2013 and were responsible for $25 \%$ of all Alzheimer's disease-related hospitalizations 10.

Although information about hospitalization due to ischemic heart disease 11, overweight, and obesity 12 is available, the information concerning Alzheimer's disease-related hospitalizations in Brazil is scarce despite its economic and social impact 1,3,4. As such, this study describes the trend of number, duration, and economic cost from hospitalizations related to Alzheimer's disease in Brazil from 2010 to 2019.

\section{Methods}

For this time-series, retrospective, descriptive study, we collected data from Brazilian Informatics Department of SUS (DATASUS. http://www.datasus.gov.br). We extracted the number of hospital admissions, total days hospitalized, and total costs of hospitalizations from 2010 to 2019, which was the latest year with available data.

Total hospitalizations were considered as any new authorized hospitalization form, transferences, and re-hospitalization related to Alzheimer's disease. To account for population size and growth, we divided the number of hospital admissions by the total population size. For stratified analysis, we divided the number of hospitalizations by the population size in each subgroup (i.e., sex, age group, ethnicity, and region) for each year. The number of inhabitants was obtained using the 2010 National Census (Instituto Brasileiro de Geografia e Estatística. http://www.ibge.gov.br) and the Continuous Brazilian National Household Survey (PNAD Contínua, in Portuguese. https://www.ibge.gov.br/en/ statistics/social/labor/16833-monthly-dissemination-pnadc1.html?=\&t=o-que-e, accessed on 10/ Mar/2020).

Mean days hospitalized was calculated by dividing the total in-hospital days of all hospitalizations by the number of hospital admissions during the 10-year period. Hospitalization duration was calculated based on admission and discharge. For example, if the patient was admitted on January 15 st and discharged on January 18th, that would be a 3-days hospitalization.

Total costs was considered as the value referred to all hospitalizations during a specific period. Values from each year were adjusted to the inflation rate based on the Extended National Consumer Price Index (IPCA) (Banco Central do Brasil. Correção de valores. https://www3.bcb.gov.br/CAL CIDADAO/publico/exibirFormCorrecaoValores.do? method=exibirFormCorrecaoValores\&aba=1, accessed on 13/Oct/2020), enabling direct comparison among the years. 
The cause of hospitalizations was informed as the main diagnosis, defined as what caused the hospitalization. For Alzheimer's disease, we considered all hospitalizations from which the main diagnose were Alzheimer's Disease defined as G30.0 to G30.9 according to the International Classification of Disease, 10th revision (ICD-10) 13.

We also stratified these outcomes by sex (male/female), age groups based on birth and admission days (less than 50, 50-59, 60-69, 70-79, 80 or older), ethnicity (white, black, mixed, yellow, and indigenous), type of admission (emergency or elective), and region (South, Southeast, North, Northeast, and Central West). After data collection, we calculated the percent changes in our outcomes from 2010 to 2015 and then from 2015 to 2019 . Values from Asian and indigenous people were not shown due to missing data in most of the years for all outcomes.

Total hospitalizations, rate of hospitalization, mean days hospitalized, and absolute and relative costs from these hospitalizations were also collected from DATASUS for hospitalizations due to ischemic heart disease (ICD-10: I20-I25), cerebrovascular disease (ICD-10: I60-I69), diabetes mellitus (E10-E14), and chronic obstructive pulmonary disease (J40-J44), that were the first, second, fifth, and seventh leading causes of death in Brazil in 2017, and with Alzheimer's disease they were the top-5 non-communicable chronic diseases that served as cause of death (Departamento de Análise em Saúde e Vigilância das Doenças Não Transmissíveis, Secretaria de Vigilância em Saúde. Principais causas de morte. http://svs.aids.gov.br/dantps/centrais-de-conteudos/paineis-de-monitoramento/ mortalidade/gbd-brasil/principais-causas/, accessed on 16/Oct/2020). We used those data to compare changes of our outcomes from 2010 to 2019 among these diseases. After importing into Stata 13.1 (https://www.stata.com), data was reported in absolute and relative values, and changes were described in percent.

To test time trend in number, duration, and cost of hospitalizations due to Alzheimer's disease from 2010 to 2019 in Brazil, the Prais-Winsten regression method was used, with Corchrane-Orcutt transformation and search for rho to minimize the sum-of-squared errors of the transformed equation. This test corrects the first-order autocorrelation effect and quantifies the annual variation in number, rate (per 100,000 inhabitants), duration (days), and cost (BRL) of hospitalization due to Alzheimer's disease in Brazil throughout that period 14. Regression coefficients classified time trend as increased or decreased if $\mathrm{p}<0.05$ and coefficient higher or lower than 0 , respectively. If $\mathrm{p}>0.05$, trend was classified as stationary. Since public data were available in DATASUS and in Brazilian Institute of Geography ansd Statistics (IBGE, in Portuguese) website, approval by the Ethics Research Committee was not needed.

\section{Results}

We observed an increase of $87.7 \%$ in hospitalizations due to Alzheimer's disease in Brazil from 2010 to 2019 (Table 1). This increase was even greater among men (97.4\%), mixed ethnicity (224\%), those aged 80 years or older (115.1\%), and in Northeast (172.1\%), Central West (144.2\%), and Southeast (91.6\%) regions of Brazil. Further, the time trend of the number of hospital admissions during that 10 -year period did not achieve statistical significance only in patients aged 50 years or younger $(\mathrm{p}=$ $0.105)$, admitted as elective $(\mathrm{p}=0.099)$, and in the Southeast $(\mathrm{p}=0.057)$ and North $(\mathrm{p}=0.097)$ regions.

Even though there was a decrease in hospitalizations due to Alzheimer's disease among black individuals from 2010 to 2015 (-20.4\%), this ethnicity was more hospitalized from 2015 to 2019 (105.1\%). On the other hand, women, subjects aged 79 or less, admission on hospital by elective, and patients from the Southeast and North regions had an increase in hospitalizations from 2010 to 2015, followed by decrease from 2015 to 2019.

Furthermore, Table 2 summarizes the hospitalization rate attributable to Alzheimer's disease from 2010 to 2019 in Brazil. Our findings showed that, in this 10-year period, the hospitalization rate increased $75.3 \%$ in the country, with higher values in patients self-declared white $(76.7 \%)$ and mixed ethnicity (192.8\%), from Southeast (91.6\%), Central West (119.2\%), and Northeast (158.9\%). Nevertheless, only patients aged 50 years or younger presented a decrease in this indicator $(-43.6 \%)$.

We also revealed an increasing trend in the rate of hospitalizations per 100,000 inhabitants from 2010 to 2019 in Brazil (0.04; 95\%CI: 0.01; 0.08) and in the South (0.03; 95\%CI: 0.03; 0.05), Northeast 
Table 1

Trend from 2010 to 2019 in hospitalizations associated to Alzheimer's disease in Brazil.

\begin{tabular}{|c|c|c|c|c|c|c|c|c|c|}
\hline & \multicolumn{6}{|c|}{ Hospitalization } & \multirow{3}{*}{$\begin{array}{c}\text { Difference per } \\
\text { year * }\end{array}$} & \multirow[t]{3}{*}{$95 \% \mathrm{Cl}$ * } & \multirow[t]{3}{*}{ p-value } \\
\hline & 2010 & 2015 & 2010-2015 & 2019 & 2010-2019 & 2015-2019 & & & \\
\hline & $\mathbf{n}$ & $\mathbf{n}$ & $\%$ & $\mathbf{n}$ & $\%$ & $\%$ & & & \\
\hline Brazil & 847 & 1,614 & 90.6 & 1,590 & 87.7 & -1.5 & 99.0 & $33.9 ; 164.1$ & 0.009 \\
\hline \multicolumn{10}{|l|}{ Sex } \\
\hline Male & 273 & 546 & 100.0 & 539 & 97.4 & -1.3 & 26.2 & $0.3 ; 52.1$ & 0.048 \\
\hline Female & 574 & 1,068 & 86.1 & 1,051 & 83.1 & -1.6 & 70.3 & $28.9 ; 111.7$ & 0.005 \\
\hline \multicolumn{10}{|l|}{ Ethnicity } \\
\hline White & 455 & 766 & 68.4 & 788 & 73.2 & 2.9 & 38.7 & $23.8 ; 53.6$ & $<0.001$ \\
\hline Black & 49 & 39 & -20.4 & 80 & 63.3 & 105.1 & 2.0 & $0.4 ; 3.7$ & 0.002 \\
\hline Mixed & 100 & 312 & 212.0 & 324 & 224.0 & 3.8 & 27.7 & $18.7 ; 36.6$ & $<0.001$ \\
\hline \multicolumn{10}{|l|}{ Age group (years) } \\
\hline Less than 50 & 27 & 39 & 44.4 & 15 & -44.4 & -61.5 & -1.6 & $-3.6 ; 0.4$ & 0.105 \\
\hline $50-59$ & 29 & 39 & 34.5 & 33 & 13.8 & -15.4 & 1.6 & $0.4 ; 2.9$ & 0.015 \\
\hline $60-69$ & 84 & 160 & 90.5 & 154 & 83.3 & -3.8 & 9.9 & $4.6 ; 15.1$ & 0.003 \\
\hline $70-79$ & 276 & 484 & 75.4 & 461 & 67.0 & -4.8 & 23.3 & $1.1 ; 45.6$ & 0.042 \\
\hline 80 or older & 431 & 892 & 107.0 & 927 & 115.1 & 3.9 & 65.2 & $28.4 ; 102.1$ & 0.004 \\
\hline \multicolumn{10}{|c|}{ Type of admission } \\
\hline Emergency & 674 & 1,211 & 79.7 & 1,307 & 93.9 & 7.9 & 73.8 & $42.7 ; 104.9$ & 0.001 \\
\hline Elective & 173 & 403 & 132.9 & 283 & 63.6 & -29.8 & 26.2 & $-6.4 ; 58.8$ & 0.099 \\
\hline \multicolumn{10}{|l|}{ Region } \\
\hline South & 238 & 337 & 41.2 & 366 & 53.8 & 8.9 & 13.0 & $7.8 ; 18.1$ & 0.001 \\
\hline Southeast & 467 & 1,040 & 122.7 & 895 & 91.6 & -13.9 & 55.6 & $-2.2 ; 113.4$ & 0.057 \\
\hline North & 31 & 42 & 35.5 & 39 & 25.8 & -7.1 & 2.0 & $-0.5 ; 4.4$ & 0.097 \\
\hline Northeast & 68 & 145 & 113.2 & 185 & 172.1 & 27.6 & 15.8 & $10.5 ; 21.2$ & $<0.001$ \\
\hline Central West & 43 & 51 & 18.6 & 105 & 144.2 & 105.9 & 11.6 & $8.5 ; 14.8$ & $<0.001$ \\
\hline
\end{tabular}

95\%Cl: 95\% confidence interval.

* Expressed in average change in number of hospitalizations due to Alzheimer disease per year in Brazil from 2010 to 2019.

(0.03; 95\%CI: 0.02; 0.04), and Central West (0.07; 95\%CI: 0.05; 0.09) regions. This trend was also identified in all sex and ethnic groups. On the other hand, no trend in hospitalization rate was identified by different age groups.

Table 3 summarizes the trend in mean duration of hospitalizations. Our findings revealed a reduction in mean days hospitalized from 2010 to 2019 in all groups, with remarkable changes in patients aged between 60 and 69 years old (54.8\%), mixed ethnicity (64.5\%), patients in the Northeast Region $(67.7 \%)$ and aged 50 or younger (71.2\%). Nevertheless, in patients aged 50 and 59 years old the mean duration of hospital admissions raised by $26.7 \%$ between 2015 and 2019.

Likewise, mean days hospitalized have been decreasing annually among white (4.3; 95\%CI: -8.02; $-0.65)$ and mixed ethnicity patients $(2.54$; 95\%CI: $-3.47 ;-1.60)$. Significant annual changes were also observed in patients aged 60-69 (-5.40; 95\%CI: -8.12 ; -2.68$)$ and 80 or older $(-1.61$; 95\%CI: -2.63 ; -0.59) and were independent of type of admission. While four of five regions revealed briefer hospital stays during the 10-year period, only the Central West Region indicates an increasing trend in days hospitalized per year $(0.75$; 95\%CI: 0.30; 1.19).

The economic cost from hospitalizations due to Alzheimer's disease in Brazil increased 41.6\% from 2010 to 2019, as shown in Table 4. In hospitalizations whose patients were from the South Region (43\%), men (51.9\%), aged 80 years or older (87.3\%), admitted by emergency services (98.9\%), and from the Central West Region (793.4\%), the increase was higher than the average. 
Trend from 2010 to 2019 in hospital admission due to Alzheimer's disease per 100,000 inhabitants in Brazil.

\begin{tabular}{|c|c|c|c|c|c|c|c|c|c|}
\hline & \multicolumn{6}{|c|}{ Hospitalization } & \multirow{3}{*}{$\begin{array}{c}\text { Difference per } \\
\text { year ** }\end{array}$} & \multirow[t]{3}{*}{$95 \% \mathrm{Cl}$ ** } & \multirow[t]{3}{*}{ p-value } \\
\hline & 2010 * & $2015 *$ & $2010-2015$ & 2019 * & 2010-2019 & 2015-2019 & & & \\
\hline & & & $\%$ & & $\%$ & $\%$ & & & \\
\hline Brazil & 0.43 & 0.80 & 83.8 & 0.76 & 75.3 & -4.6 & 0.040 & $0.01 ; 0.08$ & 0.019 \\
\hline \multicolumn{10}{|l|}{ Sex } \\
\hline Male & 0.29 & 0.55 & 91.1 & 0.53 & 84.2 & -3.6 & 0.020 & $0.00 ; 0.05$ & 0.047 \\
\hline Female & 0.56 & 1.02 & 81.1 & 0.97 & 71.9 & -5.1 & 0.06 & $0.03 ; 0.09$ & 0.004 \\
\hline \multicolumn{10}{|l|}{ Ethnicity } \\
\hline White & 0.50 & 0.83 & 66.2 & 0.88 & 76.7 & 6.3 & 0.050 & $0.04 ; 0.05$ & $<0.001$ \\
\hline Black & 0.34 & 0.25 & -26.6 & 0.40 & 18.8 & 61.9 & 0.030 & $0.02 ; 0.04$ & 0.001 \\
\hline Mixed & 0.11 & 0.33 & 188.5 & 0.33 & 192.8 & 1.5 & 0.030 & $0.02 ; 0.04$ & $<0.001$ \\
\hline \multicolumn{10}{|l|}{ Age group (years) } \\
\hline Less than 50 & 0.01 & 0.02 & 44.3 & 0.01 & -43.6 & -60.9 & -0.001 & $-0.001 ;-0.000$ & 0.027 \\
\hline $50-59$ & 0.14 & 0.17 & 25.3 & 0.13 & -8.2 & -26.7 & 0.004 & $-0.004 ; 0.011$ & 0.315 \\
\hline $60-69$ & 0.60 & 1.01 & 66.8 & 0.84 & 39.8 & -16.2 & 0.040 & $0.01 ; 0.06$ & 0.028 \\
\hline $70-79$ & 3.61 & 5.70 & 58.0 & 4.71 & 30.5 & -17.4 & 0.110 & $-0.20 ; 0.42$ & 0.425 \\
\hline 80 or older & 12.18 & 22.36 & 83.5 & 19.24 & 57.9 & -13.9 & 0.630 & $-0.76 ; 2.03$ & 0.319 \\
\hline \multicolumn{10}{|l|}{ Region } \\
\hline South & 0.85 & 1.16 & 36.8 & 122 & 44.0 & 5.3 & 0.040 & $0.03 ; 0.05$ & $<0.001$ \\
\hline Southeast & 0.57 & 1.21 & 115.0 & 1.01 & 91.6 & 79.3 & 0.058 & $0.003 ; 0.113$ & 0.043 \\
\hline North & 0.19 & 0.25 & 28.5 & 0.21 & 13.1 & -12.0 & 0.010 & $-0.01 ; 0.02$ & 0.189 \\
\hline Northeast & 0.13 & 0.26 & 106.0 & 0.33 & 158.9 & 27.6 & 0.030 & $0.02 ; 0.04$ & $<0.001$ \\
\hline Central West & 0.30 & 0.33 & 12.3 & 0.65 & 119.2 & 95.1 & 0.070 & $0.05 ; 0.09$ & $<0.001$ \\
\hline
\end{tabular}

95\% Cl: 95\% confidence interval.

* Expressed in number of hospitalizations due to Alzheimer's disease per 100,000 inhabitants;

** Expressed in average change in number of hospitalizations due to Alzheimer's disease per 100,000 inhabitants in Brazil. Values were calculated from the Prais-Winsten regression.

Furthermore, black people had a decrease in service costs at the hospital (-9.6\%) from 2010 to 2015. Nevertheless, between 2015 and 2019, these values increased by $31.8 \%$. A similar pattern was observed from patients younger than 50 years where the values increased by $69.6 \%$ between 2015 to 2019.

The variation coefficient indicates the cost from hospitalizations due to Alzheimer's disease increased annually from 2010 to 2019 among women (BRL 65.99; 95\%CI: 11.30; 1220.68), black (BRL 23.09; 95\%CI: 13.29; 32.90) and mixed (BRL 20.22; 95\%CI: 5.13; 35.32) ethnic groups, patients aged between 70 and 79 years (BRL 35.79; 95\%CI: 12.81; 58.76), and in emergency-related hospital admissions (BRL 122.74; 95\%CI: 97.08; 148.41). Likewise, while costs from those hospital services increased annually in the North (BRL 1.56; 95\%CI: 0.29; 2.82) and Central West regions (BRL 12.02; 95\%CI: $6.51 ; 17.53$ ), it decreased in elective admission (BRL -722,29; 95\%CI: -1,190.40; -240,18).

Moreover, Supplementary Material (http://cadernos.ensp.fiocruz.br/static//arquivo/supple000733-20_7798.pdf) describes the mean cost per hospital admission by Alzheimer's disease in Brazil from 2010 to 2019. In contrast with the absolute values, the mean cost of these hospitalizations had a decreasing trend from 2009 to 2019 in women (BRL -93,02; 95\%CI: -156.91; -29.12) and mixed ethnicity people (BRL $-170,11$; 95\%CI: -250.81 ; -89.41$)$. Also, only patients aged 50 or younger (BRL 214.19; 95\%CI: 46.40; 381.98) presented increasing annual variation in this indicator. The highest decreasing trend was observed in patients admitted by elective services (BRL -1,004.42; 95\%CI: $-1,613.69 ;-395.14)$, followed by those aged 60 to 69 years (BRL -335.93 ; 95\%CI: -543.64; -128.21), and those living in the Southeast Region (BRL -272.87; 95\%CI: -421.59; -124.15). 
Table 3

Trend from 2010 to 2019 in mean days hospitalized a due to Alzheimer's disease in Brazil.

\begin{tabular}{|c|c|c|c|c|c|c|c|c|c|}
\hline & \multicolumn{6}{|c|}{ Mean duration (days) } & \multirow{3}{*}{$\begin{array}{c}\text { Difference per } \\
\text { year ** }\end{array}$} & \multirow[t]{3}{*}{$95 \% \mathrm{Cl} * *$} & \multirow[t]{3}{*}{ p-value } \\
\hline & 2010 * & 2015 * & 2010-2015 & 2019 * & 2010-2019 & 2015-2019 & & & \\
\hline & & & $\%$ & & $\%$ & $\%$ & & & \\
\hline Brazil & 31.02 & 25.20 & -18.8 & 19.55 & -37.0 & -22.4 & -1.51 & $-2.06 ;-0.96$ & $<0.001$ \\
\hline \multicolumn{10}{|l|}{ Sex } \\
\hline Male & 30.49 & 26.64 & -12.6 & 20.21 & -33.7 & -24.1 & -1.14 & $-2.04 ;-0.24$ & 0.020 \\
\hline Female & 31.27 & 24.46 & -21.8 & 19.17 & -38.7 & -21.6 & -1.68 & $-2.27 ;-1.08$ & $<0.001$ \\
\hline \multicolumn{10}{|l|}{ Ethnicity } \\
\hline White & 29.73 & 30.64 & 3.1 & 20.22 & -32.0 & -34.0 & -4.33 & $-8.02 ;-0.65$ & 0.027 \\
\hline Black & 65.41 & 72.77 & 11.3 & 46.83 & -28.4 & -35.6 & -2.35 & $-5.19 ;-0.49$ & 0.091 \\
\hline Mixed & 47.91 & 22.58 & -52.9 & 17.03 & -64.5 & -24.6 & -2.54 & $-3.47 ;-1.60$ & $<0.001$ \\
\hline \multicolumn{10}{|l|}{ Age group (years) } \\
\hline Less than 50 & 37.22 & 12.82 & -65.6 & 10.73 & -71.2 & -16.3 & 0.30 & $-2.09 ; 2.69$ & 0.773 \\
\hline $50-59$ & 39.03 & 23.97 & -38.6 & 30.36 & -22.2 & 26.7 & 1.50 & $-1.56 ; 4.57$ & 0.284 \\
\hline $60-69$ & 43.85 & 36.63 & -16.5 & 19.80 & -54.8 & -45.9 & -5.40 & $-8.12 ;-2.68$ & 0.002 \\
\hline $70-79$ & 32.29 & 21.66 & -32.9 & 21.18 & -34.4 & -2.2 & -0.50 & $-1.94 ; 0.93$ & 0.434 \\
\hline 80 or older & 26.77 & 25.67 & -4.1 & 18.44 & -31.1 & -28.2 & -1.61 & $-2.63 ;-0.59$ & 0.007 \\
\hline \multicolumn{10}{|l|}{ Type of admission } \\
\hline Emergency & 17.84 & 14.46 & -18.9 & 12.23 & -31.4 & -15.4 & -0.80 & $-1.59 ;-0.01$ & 0.047 \\
\hline Elective & 82.36 & 57.47 & -30.2 & 53.35 & -35.2 & -7.2 & -7.21 & $-13.29 ;-1.14$ & 0.026 \\
\hline \multicolumn{10}{|l|}{ Region } \\
\hline South & 16.05 & 12.00 & -25.2 & 10.78 & -32.8 & -10.2 & -0.50 & $-0.85 ;-0.14$ & 0.014 \\
\hline Southeast & 38.37 & 31.65 & -17.5 & 25.31 & -34.0 & -20.0 & -1.99 & $-2.81 ;-1.18$ & 0.001 \\
\hline North & 6.16 & 7.07 & 14.8 & 4.78 & -22.4 & -32.4 & -0.78 & $-1.14 ;-0.43$ & 0.001 \\
\hline Northeast & 56.16 & 20.10 & -64.2 & 18.16 & -67.7 & -9.7 & -3.88 & $-7.00 ;-0.76$ & 0.022 \\
\hline Central West & 12.07 & 10.23 & -15.2 & 8.94 & -25.9 & -12.6 & 0.75 & $0.30 ; 1.19$ & 0.005 \\
\hline
\end{tabular}

95\%Cl: 95\% confidence interval.

* Total days hospitalized divided by the total number of hospital admissions;

** Expressed in average change in number of days hospitalized due to Alzheimer's disease per year in Brazil from 2010 to 2019.

Compared to the top-5 non-communicable chronic diseases that serve as cause of death in Brazil, Alzheimer's disease showed the highest and third-highest increase in disease-related hospitalization rate per 100,000 inhabitants (Figure 1a; 75\%) and total costs from hospitalizations (Figure 1c; 42\%), respectively. On the other hand, the greatest reduction in mean days hospitalized and costs per admission were from patients with Alzheimer's disease (Figure 1b; 41\%; Figure 1d; 25\%).

\section{Discussion}

This was the first national-based, time-series study that described hospital admissions from Alzheimer's disease in Brazil. We reported that total (87.7\%) and rate (75.3\%) of hospitalizations and total cost from hospitalization (41.6\%) due to Alzheimer's disease increased from 2010 to 2019 in Brazil, indicating an increase in hospitalizations over this 10-year interval in Brazil. On the other hand, mean days hospitalized (-37\%) and costs per hospitalization (-24.5\%) decreased during the same period.

Although 66\% of all hospitalization from Alzheimer's disease in 2019 were among females, the increase in hospital admission rate was higher in men (84.2\%) than women (71.9\%). Also, the annual variation coefficient indicates a time trend of increase in the absolute number and rate of hospitalization in both sexes from 2010 to 2019. In Brazil, prevalence and morbidity attributable to Alzheimer's 
Trend from 2010 to 2019 in economic cost of hospitalizations a due to Alzheimer's disease in Brazil.

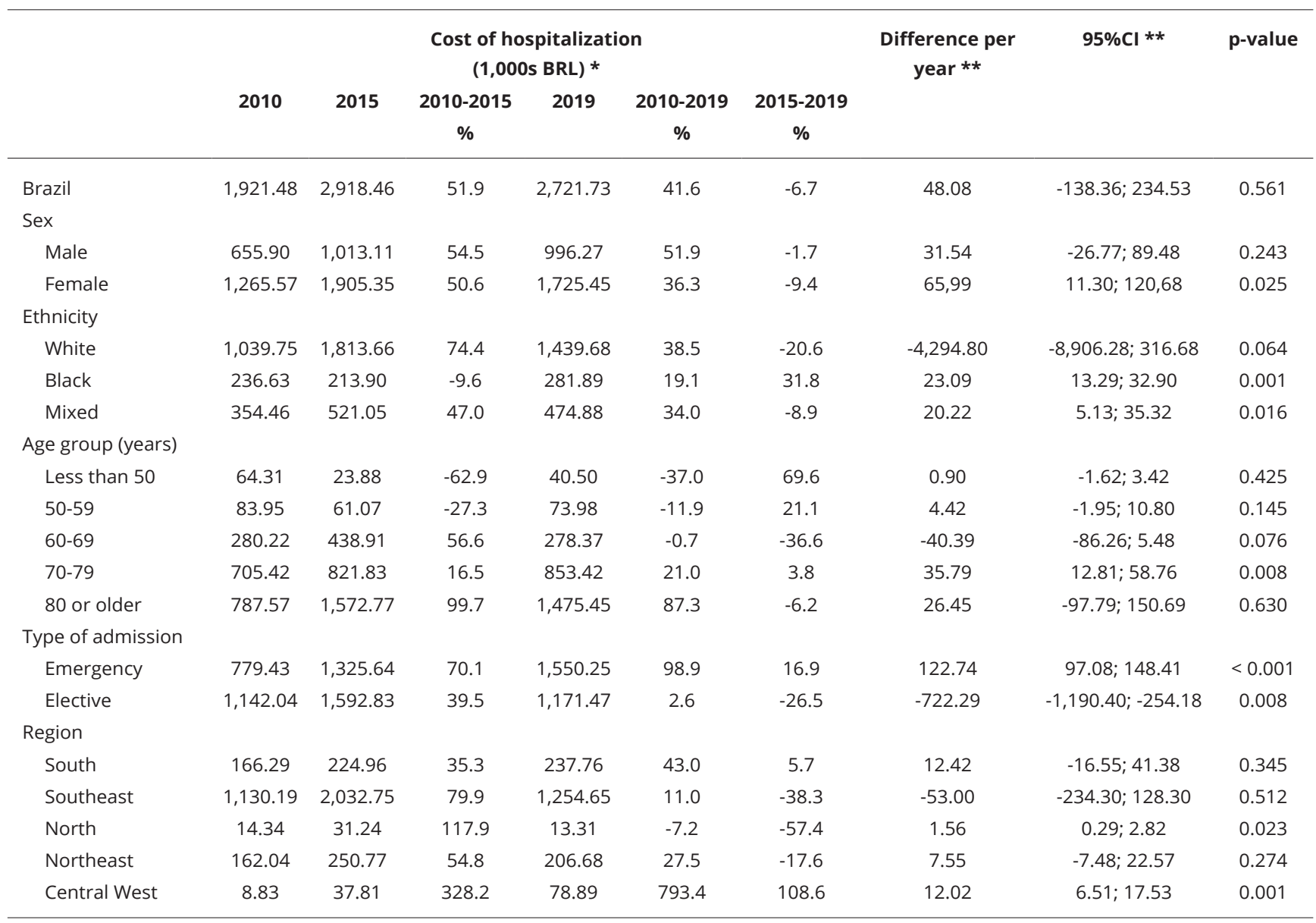

95\% Cl: 95\% confidence interval.

* Values were corrected for the inflation rate from each year (Extended National Consumer Price Index - IPCA, in Portuguese) (Banco Central do Brasil. Correção de valores. https://www3.bcb.gov.br/CALCIDADAO/publico/exibirFormCorrecaoValores.do?method=exibirFormCorrecaoValores\&aba=1, accessed on 13/Oct/2020);

** Expressed as the average change in cost of hospitalizations due to Alzheimer's disease per year in Brazil from 2010 to 2019 . Values expressed in 1,000 Brazilian Reais (BRL).

disease and other dementia were, respectively, 69\% and 68\% higher among women in 2017 (Institute for Health Metrics and Evaluation. GBD results tool. http://ghdx.healthdata.org/gbd-resultstool\%20, accessed on Oct/2020). On the other hand, women tend to present longer survival time but more affective symptoms and disability 15 , while men reported more comorbidity, decline in behavior control, and higher mortality rates 16 , which may led to an increasing need of hospital admissions.

Regarding ethnicity, white subjects accounted for $66.1 \%$ of hospitalizations due to Alzheimer's disease in 2019 at Brazil. Moreover, this ethnic group had a hospitalization rate 2.2 and 2.7 times higher than black and mixed ethnicity patients, respectively. However, we observed an increase of about $105.1 \%$ and $208.6 \%$ of hospitalization in black subjects from 2015 to 2019 and in mixed ethnicity from 2010 to 2019. This relative change was corroborated by the positive and significant annual percentage change in those ethnic groups. Husaini et al. 17 reported that besides a gender disparity in prevalence of dementia, there is also an ethnic disparity, with higher prevalence among black women and men compared to whites. According to the IBGE 18, the self-declared black population increased 7.4\% from 2012 to 2015, and 23.1\% from 2015 to 2018, and mixed ethnicity became the most prevalent ethnicity in Brazil (46.5\%). 


\section{Figure 1}

Percentage changes in hospitalization rate per 100,000 inhabitants, mean days hospitalized, and total and mean cost from hospitalization due to top-5 cause of death non-communicable chronic disease in Brazil, 2010-2019.

1a) Hospitalization rate per 100,000 inhabitants (\%)

Chronic obstructive pulmonary disease

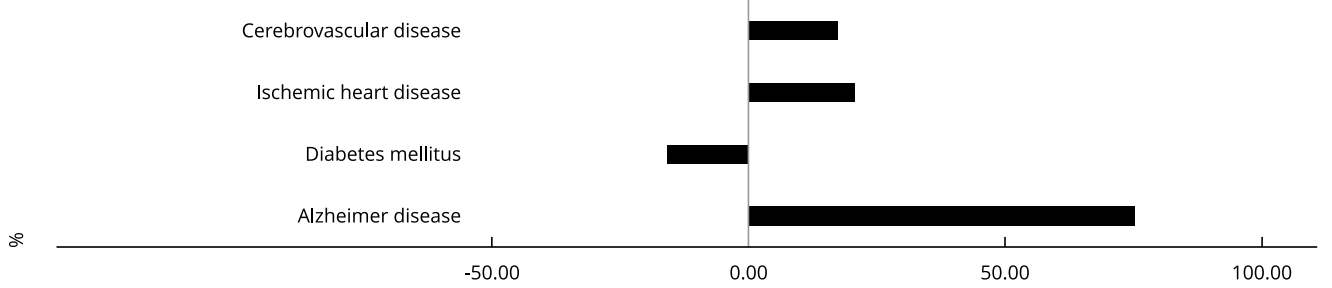

1b) Mean days hospitalized (\%)

Chronic obstructive pulmonary disease

Cerebrovascular disease

Ischemic heart disease

Diabetes mellitus

Alzheimer disease

\&

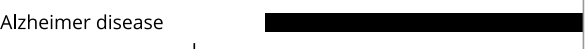

$-50.00$

0.00

1c) Total economic cost of hospitalization (\%)

Chronic obstructive pulmonary disease

Cerebrovascular disease

Ischemic heart disease

Diabetes mellitus

Alzheimer disease

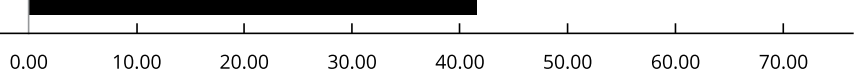

1d) Mean economic cost per hospitalization (\%)

Chronic obstructive pulmonary disease

Cerebrovascular disease

Ischemic heart disease

Type 2 diabetes

2

Alzheimer disease

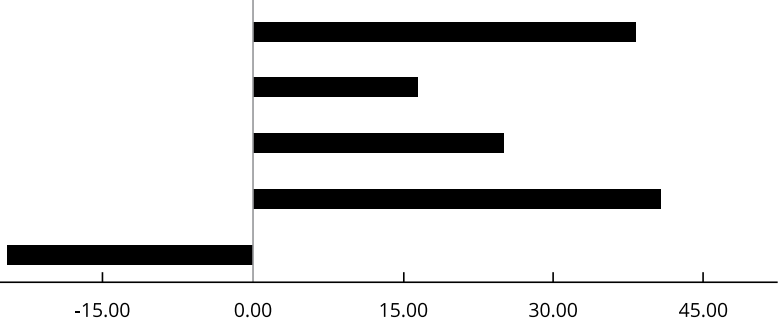


Death by cerebrovascular disease, hypertension and diabetes contributed for the "white-black" gap in life expectancy in Brazil, with black and mixed ethnicity individuals dying earlier by those chronic conditions 19. Previous researchers have suggested that the elevated prevalence and incidence of cognitive impairment and dementia in these groups are associated with increased vascular risk induced by health disparities-related stress 20 . Cumulative stress throughout life affects neural mechanisms contributing to cognitive impairment 21 . Also, disparities in stressful events are associated with building environment, employment status, access to health care services, and social support. As a result, patients might present the first signals of dementia when the disease is at more advanced stages, ultimately increasing the number of admissions from emergency services 20 . In this vein, strategies to increase awareness about prevention, diagnoses, and treatment of dementia must be promoted at population level, especially in these ethnic groups.

The Brazilian population is ageing. From 2000 to 2050, the prevalence of people living with at least 60 years will increase by $280 \% 22$. The most important risk factor for Alzheimer's disease is age, with the prevalence of the disease doubling every 5 years after age 652 . This fact could explain the $115.1 \%$ increase in hospitalization for patients aged 80 or older. Although the youngest age group $<$ 50 years-old) had a decrescent trend from 2010 to 2019 in hospitalization rate, the mean economic cost changed in the opposite direction. Early-onset Alzheimer's disease included cases of Alzheimer's disease onset before age 6523 and is associated in most cases with genetic mutations 2,24. People with this condition are more likely to present more brain changes related to Alzheimer's disease 25,26, which could be associated with the increased cost per admission. Although it is estimated to represent about $5 \%$ of all Alzheimer's disease cases in the world 27, no data about the prevalence of this type of Alzheimer's disease in the Brazilian population is available 28. Early-onset Alzheimer's disease is poorly understood, underdiagnosed, and inadequately treated, leading to underestimation of the impact of this condition on the healthcare system 28,29. Future population-based studies that aim to describe the people with Alzheimer's disease and its sub-types in Brazil are encouraged.

The prevalence of Alzheimer's disease and other dementia in 2017 were higher in subjects aged from 60 to 74 years old in Brazil compared to United States, Canada, and Australia (Institute for Health Metrics and Evaluation. GBD results tool. http://ghdx.healthdata.org/gbd-results-tool\%20, accessed on Oct/2020), which could be related to earlier onset of disease in most prevalent ethnicities 19 . Also, the country has made progress in the public health agenda concerning dementia control, especially in providing high cost medication free of charge for patients with dementia ${ }^{30}$. However, the difficult diagnosis for Alzheimer's disease and related disorders may lead to longer hospital stays and more screenings to possible diagnoses. Then, more training and resources for diagnosis of dementia, better long-term management provide by health professionals, and improved knowledge about risk factors for dementia and how to control them need to be done to reduce the hospital-related burden of Alzheimer in all age groups 31 .

Also related to disease management is the major type of admission switch from elective to emergency from 2010 to 2019. Indeed, the cost of emergency-related admissions due to Alzheimer's disease increased annually about BRL 122,744.60 (95\%CI: 97,079.92; 148,409.40), whereas the cost from elective admission decreased by on average BRL 722,290.40 (95\%CI: -1,190,403.00; -254,177.30) during this 10-year period. A similar pattern was observed in the United Kingdom, where admissions from emergency services increased from 2008 to 2016 32. In the United States, the average emergency department visit is 1,471 per 1,000 older people with Alzheimer's disease 33. Moreover, Alzheimer's disease patients are more likely to have a potentially avoidable emergency visit that resulted in hospitalization ${ }^{33}$. LaMantia et al. 34 explained that age, ethnicity, number of comorbidities and hospitalization were predictors of emergency department visits in the United States. As mentioned, the Brazilian population is ageing and more self-declared black 18, and Alzheimer's disease is strictly related to higher prevalence of comorbidities 3 . Likewise, the underdiagnoses of dementia led to an increase in use of emergency settings. While the national underdetection rate in United Kingdom is about $52 \%$, in Brazil this number may reach $77 \% 31$. Attached to low awareness and attitudes towards dementia and its care, these factors may result in failure to seek help and treatment 35 , leading to an increase in emergency setting admission from Alzheimer's disease patients.

Our findings indicate an annual rise in hospitalization rate from 2010 to 2019 in the South, Northeast, Central West, and Southeast regions. Regarding hospitalization duration, we observed an 
annual reduction in four of the five Brazilian regions, with the only crescent trend being observed in the Central West Region. Similarly, the morbidity associated with Alzheimer's disease increased by 153\% from 2010 to 2019 in Central West Region while it decreased by 6\% in the Southeast in the same period (Institute for Health Metrics and Evaluation. GBD results tool. http://ghdx.healthdata.org/ gbd-results-tool\%20, accessed on Oct/2020). Indeed, older population in the Central West Region increased 42\% from 2010 to 2017 primarily due to migration of people from other Brazilian regions 18 . Together, those facts may explain the change of hospitalizations due to Alzheimer's disease in those regions.

From 2010 to 2019, Alzheimer's disease had the highest increase in number and rate of hospitalizations among the top- 5 causes of death by non-communicable disease in Brazil. For example, the observed increase in hospitalization per 100,00 inhabitants attributable to Alzheimer's disease was $330 \%$ and $263 \%$ higher than for cerebrovascular and ischemic heart diseases, respectively. Based on annual rate change, we projected that in 2050, more people will be hospitalized in Brazil due to Alzheimer's disease than chronic obstructive pulmonary disease. At Central West and Northeast regions, Alzheimer's disease will overcome diabetes in number of hospital admissions in 2048 and 2035 , respectively.

Similarly, the growth in costs of Alzheimer's disease in hospital settings from 2010 to 2019 was 785\% higher than chronic obstructive pulmonary disease and 53\% higher than diabetes mellitus. Although mortality rate by Alzheimer's disease decreased from 19.1 to 13.7 between 2010 to 2015, it increased throughout the following years by up to 24.2 in 2019, the highest increase in mortality rate from 2015 to 2019 (DATASUS. http://www.datasus.gov.br). That made Alzheimer's disease the disease with the third-highest all-cause mortality rate in Brazil in 2019 (24.1\%), followed by septicemia (44.7\%) and malignant neoplasia in the trachea, lungs, and bronchus (26.8\%). In the United States, the percentage of death by Alzheimer's disease increased by 145\% from 2000 to 2017 33, killing more than breast and prostate cancer combined 36.

Alzheimer's disease already costs USD 1 trillion worldwide, and it is estimated that this value will double in the next 30 years ${ }^{37}$. Just in the United States, early and accurate diagnosis could save up to USD 7.9 trillion 36. In Brazil, about 32.3\% of Alzheimer's disease prevalence is due to modifiable risk factors such as diabetes mellitus, midlife hypertension and obesity, physical inactivity, depression, smoking, and low educational attainment 38 . Considering a $20 \%$ reduction per decade among those aforementioned risk factors by 2050, there would be 604,000 less cases of dementia in Brazil and USD 10.3 million in disease-related costs could be saved 38. Although our findings revealed a decrease in the mean costs per hospitalization, this indicator increased annually in young patients and patients admitted by emergency services. For most people worldwide, Alzheimer's disease is still perceived as a non-preventable condition that is a normal part of ageing 39 . Health policies to increased awareness of Alzheimer's disease and preventive strategies need to be stimulated.

The main limitation of this study is its descriptive design. Nevertheless, this type of investigation is relevant in Brazil as it led to a broader view of the current situation of Alzheimer's disease in Brazil. This is the first time-series national-based study that descripted total number of hospitalizations, hospitalized days and the related costs attributable to Alzheimer's disease in Brazil. The prevalence of this disease will triple by 2050 38, affecting more than 3 million people, and only 1 in 4 cases of dementia are diagnosed 30 . As a result, public health policies, such as high-cost medication available free-ofcharge, have been delineated to reduce the burden of Alzheimer's disease in the country. Nevertheless, much more needs to be done. Alzheimer's disease in underdiagnosed, undertreated, and much of these come from under-recognition and undermanagement 40.

In conclusion, Alzheimer's disease is already a public health problem in Brazil. The number, duration, and the costs of hospitalizations due to this disease increased more than other top- 5 causes of death by non-communicable chronic diseases from 2010 to 2019. Strategies to reduce the burden of Alzheimer's disease in Brazil are necessary but only if followed by greater equality and awareness of this disease. 


\section{Contributors}

All authors contributed equally to the draft of the manuscript and made critical revisions thereof.

\section{Additional informations}

ORCID: Natan Feter (0000-0001-6295-9792); Jayne Santos Leite (0000-0002-4612-7301); Samuel Carvalho Dumith (0000-0002-5994-735X); Airton José Rombaldi (0000-0002-6707-814X).

\section{Acknowledgments}

This study was funded in part by the Brazilian Graduate Studies Coordinationg Board (CAPES).

\section{References}

1. Nichols E, Szoeke CEI, Vollset SE, Abbasi N, Abd-Allah F, Abdela J, et al. Global, regional, and national burden of Alzheimer's disease and other dementias, 1990-2016: a systematic analysis for the Global Burden of Disease Study 2016. Lancet Neurol 2019; 18:88-106.

2. Querfurth HW, LaFerla FM. Alzheimer's disease. N Engl J Med 2010; 362:329-44.

3. Teixeira JB, Souza Junior PRB, Higa J, Theme Filha MM. Mortality from Alzheimer's disease in Brazil, 2000-2009. Cad Saúde Pública 2015; 31:850-60.

4. Ferretti C, Sarti FM, Nitrini R, Ferreira FF, Brucki SMD. An assessment of direct and indirect costs of dementia in Brazil. PLoS One 2018; 13:e0193209.

5. Frota NAF, Nitrini R, Damasceno BP, Forlenza OV, Dias-Tosta E, Silva AB, et al. Criteria for the diagnosis of Alzheimer's disease: recommendations of the Scientific Department of Cognitive Neurology and Aging of the Brazilian Academy of Neurology. Dement Neuropsychol 2011; 5:146.

6. Feng Z, Coots LA, Kaganova Y, Wiener JM. Hospital and ED use among Medicare beneficiaries with dementia varies by setting and proximity to death. Health Aff 2014; 33:68390.

7. Lin P-J, Zhong Y, Fillit HM, Cohen JT, Neumann PJ. Hospitalizations for ambulatory care sensitive conditions and unplanned readmissions among Medicare beneficiaries with Alzheimer's disease. Alzheimers Dement (N Y) 2017; 13:1174-8.

8. Zilberberg MD, Tjia J. Growth in dementiaassociated hospitalizations among the oldest old in the United States: implications for ethical health services planning. Arch Intern Med 2011; 171:1850-1.

9. Palleschi L, De Alfieri W, Salani B, Fimognari FL, Marsilii A, Pierantozzi A, et al. Functional recovery of elderly patients hospitalized in geriatric and general medicine units: the PROgetto DImissioni in GEriatria Study. J Am Geriatr Soc 2011; 59:193-9.

10. Office of Disease Prevention and Health Promotion. Healthy People 2020: dementias, including Alzheimer's disease. Washington DC: Office of Disease Prevention and Health Promotion; 2010.

11. Laurenti R, Buchalla CM, Caratin CVS. Ischemic heart disease: hospitalization, length of stay and expenses in Brazil from 1993 to 1997. Arq Bras Cardiol 2000; 74:488-92.

12. Sichieri R, Nascimento S, Coutinho W. The burden of hospitalization due to overweight and obesity in Brazil. Cad Saúde Pública 2007; 23:1721-7.

13. World Health Organization. ICD-10 : international statistical classification of diseases and related health problems - tenth revision. 2nd Ed. Geneva: World Health Organization; 2004. 
14. Antunes JLF, Cardoso MRA. Uso da análise de séries temporais em estudos epidemiológicos. Epidemiol Serv Saúde 2015; 24:565-76.

15. Mazure CM, Swendsen J. Sex differences in Alzheimer's disease and other dementias. Lancet Neurol 2016; 15:451.

16. Sinforiani E, Citterio A, Zucchella C, Bono G, Corbetta S, Merlo P, et al. Impact of gender differences on the outcome of Alzheimer's disease. Dement Geriatr Cogn Disord 2010; 30:147-54.

17. Husaini B, Gudlavalleti ASV, Cain V, Levine $\mathrm{R}$, Moonis M. Risk factors and hospitalization costs of dementia patients: examining race and gender variations. Indian J Community Med 2015; 40:258-63.

18. Instituto Brasileiro de Geografia e Estatística Rio de Janeiro. Pesquisa Nacional por Amostra de Domicílios Contínua - PNAD contínua: divulgação anual. Rio de Janeiro: Instituto Brasileiro de Geografia e Estatística Rio de Janeiro; 2013.

19. Chiavegatto Filho ADP, Beltrán-Sánchez H, Kawachi I. Racial disparities in life expectancy in Brazil: challenges from a multiracial society. Am J Public Health 2014; 104:2156-62.

20. Babulal GM, Quiroz YT, Albensi BC, Arenaza-Urquijo E, Astell AJ, Babiloni C, et al. Perspectives on ethnic and racial disparities in Alzheimer's disease and related dementias: update and areas of immediate need. Alzheimers Dement (N Y) 2019; 15:292-312.

21. McEwen BS, Wingfield JC. What's in a name? Integrating homeostasis, allostasis and stress. Horm Behav 2010; 57:105.

22. World Health Organization. Global health observatory. Geneva: World Health Organization; 2019.

23. Giannakopoulos P, Hof PR, Savioz A, Guimon J, Antonarakis SE, Bouras C. Early-onset dementias: clinical, neuropathological and genetic characteristics. Acta Neuropathol 1996; 91:451-65.

24. Cummings JL. Alzheimer's disease. N Engl J Med 2004; 351:56-67.

25. Hanyu H, Nakano S, Abe S, Arai H, Iwamoto T, Takasaki M. Differences of neuroimaging between early-onset and late-onset Alzheimer-type dementia. Rinsho Shinkeigaku 1995; 35:1104-9.

26. Frisoni GB, Pievani M, Testa C, Sabattoli F, Bresciani L, Bonetti M, et al. The topography of grey matter involvement in early and late onset Alzheimer's disease. Brain 2007; 130:720-30.

27. Prince M, Wimo A, Guerchet M, Ali GC, Wu YT, Prina M. World Alzheimer Report 2015. The global impact of dementia: an analysis of prevalence, incidence, cost \& trends. London: Alzheimer's Disease International; 2015.
28. Vieira RT, Caixeta L, Machado S, Silva AC, Nardi AE, Arias-Carrión O, et al. Epidemiology of early-onset dementia: a review of the literature. Clin Pract Epidemiol Ment Health 2013; 9:88-95.

29. Engelhardt E, Laks J, Dourado MCN, Mezzasalma MAU, Carvalho-Pinto M, Chalita-Gomes A, et al. Demência pré-senil: impacto psicossocial. Rev Bras Neurol 2002; 38:5-11.

30. Nakamura AE, Opaleye D, Tani G, Ferri CP. Dementia underdiagnosis in Brazil. Lancet 2015; 385:418-9.

31. Cieto BB, Valera GG, Soares GB, Cintra RHS, Vale FAC. Dementia care in public health in Brazil and the world: a systematic review. Dement Neuropsychol 2014; 8:40-6.

32. Sommerlad A, Perera G, Mueller C, Singh-Manoux A, Lewis G, Stewart R, et al. Hospitalisation of people with dementia: evidence from English electronic health records from 2008 to 2016. Eur J Epidemiol 2019; 34:567-77.

33. Gaugler J, James B, Johnson T, Marin A, Weuve J. 2019 Alzheimer's disease facts and figures. Alzheimers Dement (N Y) 2019; 15:321-87.

34. LaMantia MA, Lane KA, Tu W, Carnahan JL, Messina F, Unroe KT. Patterns of emergency department use among long-stay nursing home residents with differing levels of dementia severity. J Am Med Dir Assoc 2016; 17:541-6.

35. Prince M, Comas-Herrera A, Knapp M, Guerchet M, Karagiannidou M. World Alzheimer Report 2016. Improving healthcare for people living with dementia: coverage, quality and costs now and in the future. London: Alzheimer's Disease International; 2016.

36. Alzheimer's Association. 2018 Alzheimer's disease facts and figures. Alzheimers Dement ( $\mathrm{N}$ Y) 2018; 14:367-429.

37. Patterson C. World Alzheimer Report 2018. The state of the art of dementia research: new frontiers. London: Alzheimer's Disease International; 2018.

38. Oliveira D, Jun Otuyama L, Mabunda D, Mandlate F, Gonçalves-Pereira M, Xavier M, et al. Reducing the number of people with dementia through primary prevention in Mozambique, Brazil, and Portugal: an analysis of populationbased data. J Alzheimers Dis 2019; 70 Suppl 1:S283-91.

39. Alzheimer's Disease International. World Alzheimer Report 2019. Attitudes to dementia. London: Alzheimer's Disease International; 2019.

40. Ferri CP, Jacob KS. Dementia in low-income and middle-income countries: different realities mandate tailored solutions. PLoS Med 2017; 14:e1002271. 


\section{Resumo}

O Brasil tem a segunda maior prevalência ajustada para idade da doença de Alzheimer no mundo. Entretanto, são escassas as informações sobre internações hospitalares por doença de Alzheimer no Brasil, apesar dos impactos econômicos e sociais da doença. $\mathrm{O}$ artigo descreve as tendências temporais nas internações hospitalares relacionadas à doença de Alzheimer no Brasil entre 2010 e 2019. Realizamos um estudo de séries temporais, retrospectivo, descritivo e de base nacional, usando dados DATASUS do Ministério da Saúde. As internações, média de dias de internação e custos econômicos das hospitalizações foram extraídos para os anos de 2010 a 2019. As internações hospitalares por doença de Alzheimer aumentaram em 87,7\% entre 2010 e 2019, com os maiores aumentos entre homens (97,4\%), pardos (224\%), indivíduos com 80 anos ou mais $(115,1 \%)$ e as regiões Nordeste (172,1\%) e Centro-oeste (144,2\%). Embora as médias de dias de internação tenham diminuido em todos os subgrupos, foi observada uma tendência temporal crescente nas internações na Região Centro-oeste. O custo por hospitalização aumentou para pacientes de 50 anos ou menos e nas internações relacionadas aos serviços de emergência. Em comparação às outras doenças crônicas não transmissíveis, a doença de Alzheimer mostrou o maior aumento no número absoluto e taxa de internações hospitalares no Brasil entre 2010 e 2019. A doença de Alzheimer é um problema de saúde pública no Brasil. São necessárias estratégias para reduzir a carga da doença, porém só serão eficazes se forem acompanhadas por maior igualdade $e$ conscientização em relação a essa doença.

Doença de Alzheimer; Hospitalização; Estudos de Séries Temporais

\section{Resumen}

Brasil cuenta con la segunda prevalencia más alta por edad estandarizada de enfermedad de Alzheimer en todo el mundo. No obstante, la información sobre las hospitalizaciones relacionadas con la enfermedad de Alzheimer en Brasil es escasa, pese a su impacto económico y social. Describimos las tendencias temporales en hospitalizaciones relacionadas con la enfermedad de Alzheimer en Brasil, desde 2010 a 2019. Realizamos un estudio de series temporales, retrospectivo, descriptivo, de base nacional, usando datos procedentes del DATASUS del Ministerio de Salud de Brasil. Las hospitalizaciones, la media de días hospitalizados, $y$ los costes económicos de estas hospitalizaciones se extrajeron desde 2010 a 2019. Las hospitalizaciones por enfermedad de Alzheimer se incrementaron un 87,7\%, desde 2010 a 2019, con un incremento más grande entre hombres (97,4\%), origen étnico mixto (224\%), 80 años o mayores $(115,1 \%)$, $y$ en las regiones del Nordeste $(172,1 \%)$ y Centrooeste (144,2\%). A pesar de que la media de dias hospitalizados decreció en todos los subgrupos, se observó una tendencia creciente en el tiempo respecto a las admisiones hospitalarias en la Región del Centro-oeste. El coste económico por hospitalización se incrementó en el caso de pacientes con 50 años o más jóvenes en las admisiones relacionadas con los servicios de emergencia. Comparado con otras enfermedades crónicas no transmisibles, la enfermedad de Alzheimer tuvo el incremento más alto en el número absoluto y tasa de hospitalizaciones en Brasil desde 2010 a 2019. La enfermedad de Alzheimer es un problema de salud público en Brasil. Las estrategias para reducir su carga son necesarias pero solamente si están acompañadas de una mayor equidad y concienciación sobre esta enfermedad.

Enfermedad de Alzheimer; Hospitalización;

Estudios de Series Temporales
Submitted on 08/Apr/2020

Final version resubmitted on 19/Oct/2020

Approved on 06/Nov/2020 